\title{
BERAUTI SPECTRAL SUBTRACTION DENGAN GAUSSIAN WINDOW UNTUK PENINGKATAN AKURASI PENGENALAN UCAPAN BERDERAU
}

\author{
Fitrilina*, Winda Alfin dan Fajar Afriyansah \\ Jurusan Teknik Elektro, Fakultas Teknik, Universitas Andalas \\ ${ }^{*}$ Corresponding author, e-mail: fitrilina@ft.unand.ac.id
}

\begin{abstract}
Abstrak - Akurasi sistem pengenalan ucapan menurun ketika digunakan pada ucapan berderau. Oleh karena itu, sistem pengenalan ucapan perlu didukung dengan metoda perbaikan sinyal ucapan. Pada penelitian ini diusulkan metoda Berauti spectral subtraction yang menerapkan gaussian window dan estimasi derau minimum statistik untuk memperbaiki kualitas sinyal berderau sehingga dapat meningkatkan akurasi pengenalan ucapan berderau. Sistem pengenalan ucapan dibangun menggunakan Hidden Markov Model ToolKit (HTK). Pada penelitian ini divariasikan tiga jenis derau, lima level SNR, enam nilai oversubtraction dan empat nilai redaman sidelobe gaussian window dengan 1500 sinyal ucapan. Peningkatan akurasi pengenalan ucapan yang menggunakan gaussian window dibandingkan dengan hamming window. Hasil penelitian ini menunjukan pemilihan nilai redaman sidelobe dan oversubtraction mempengaruhi akurasi pengenalan. Rata-rata peningkatan akurasi pengenalan ucapan sebesar 36,4 \% diperoleh pada nilai oversubtraction 4.75 dan redaman sidelobe 1.5. Penggunaan hamming window memiliki rata-rata peningkatan akurasi pengenalan sebesar $18,7 \%$ pada nilai oversubtraction 2.5. Metoda spectral subtraction yang menggunakan gaussian window atau hamming window, keduanya mampu menaikan akurasi pengenalan ucapan, akan tetapi gaussian window memiliki hasil yang lebih baik dibanding hamming window
\end{abstract}

\section{Kata Kunci : Berauti spectral subtraction, gaussian window, pengenalan ucapan}

\begin{abstract}
The accuracy of speech recognition system decreases when used on a noisy speech. Therefore, the speech recognition system needs to be supported by a speech enhancement method. This study proposes Berauti spectral subtraction method that uses gaussian window and minimum statistics noise estimation in order to improve the quality of noisy speech hence increase the accuracy of noisy speech recognition. Speech recognition system is built using the Hidden Markov Model Toolkit (HTK). This study applied three types of noise, five SNR levels, six oversubtraction values and four sidelobe gaussian window attenuation values with 1500 speech signals. Improvement of speech recognition accuracy using Gaussian window is compared with Hamming window. The results of the study shows that sidelobe and oversubtraction attenuation values affects recognition accuracy. The average speech recognition accuracy using gaussian window improve about $36.4 \%$ which is obtained at oversubtraction 4.75 and sidelobe attenuation $=1.5$. Whereas, application of hamming window improves the accuracy about $18,7 \%$ which is obtained at oversubtraction 2.5. Spectral subtraction using gaussian window or hamming window is able to improve the speech recognition accuracy, but gaussian window is better than hamming window.
\end{abstract}

Keywords : Berauti spectral subtraction, gaussian window, speech recognition

\section{Pendahuluan}

Sistem pengenalan ucapan yang robust masih merupakan permasalahan yang sulit meskipun telah banyak penelitian dilakukan [1]. Tambahan derau akustik dari lingkungan pada saat sistem digunakan menyebabkan penurunan akurasi pengenalan [2-4]. Sangat tidak mungkin membentuk sistem dengan menggunakan berbagai kondisi lingkungan dan berbagai jenis derau. Salah satu cara mengatasinya adalah sistem pengenalan ucapan dibentuk pada lingkungan tenang akan tetapi sistem dilengkapi metoda perbaikan sinyal berderau.

Pada penelitian ini metoda perbaikan sinyal berderau yang digunakan adalah spectral subtraction. Berbagai jenis metoda spectral subtraction telah dikembangkan seperti pada 
penelitian [5-8]. Metoda spectral subtraction terdiri atas tiga bagian yaitu pre-processing, estimasi derau dan pengurangan spektral. Pada bagian pre-processing, jenis window yang umum digunakan adalah hamming dan hanning[9]. Penelitian [8] mengusulkan spectral subtraction yang menggunakan gaussian window, exponentially averaging untuk estimasi derau dan metoda Boll untuk pengurangan spektral. Hasil penelitian [8] menunjukan bahwa gaussian window dengan nilai redaman side lobe yang sesuai mampu memberikan peningkatan rasio daya sinyal terhadap derau (SNR) yang lebih baik dibandingkan dengan Hamming Window. Akan tetapi, penggunaan metoda Boll memiliki kelemahan terkait musical noise yang timbul akibat pengurangan spektral [7]. Hal ini dapat diminimalkan dengan menggunakan metoda Berauti seperti pada penelitian $[6,10]$. Keakuratan estimasi derau menggunakan metoda exponentially averaging sangat tergantung pada keandalan dalam mendekteksi perioda ucapan dan perioda derau [8]. Kebutuhan pendeteksian periode ucapan dan derau dapat dieliminasi dengan menggunakan estimator derau minimum statistik [10]. Oleh karena itu, pada penelitian ini diusulkan metoda berauti spectral subtraction yang menggunakan gaussian window dan estimasi derau minimum statistik. Penelitian [5-8,10] menggunakan nilai SNR untuk mengetahui kinerja metoda spectral subtraction yang diusulkan. Penelitian [11] menunjukan peningkatan SNR pada sinyal hasil perbaikan tidak selalu menjamin peningkatan akurasi sistem pengenalan ucapan. Oleh karena itu, tujuan penelitian ini adalah melihat kinerja metoda yang diusulkan yaitu berauti spectral subtraction yang menerapkan gaussian window dan estimasi derau minimum statistik, untuk memperbaiki kualitas sinyal berderau sehingga dapat meningkatkan akurasi pengenalan ucapan berderau.

\section{Tinjauan Pustaka}

\subsection{Pembentukan Sistem Pengenalan Ucapan}

Sistem pengenalan ucapan bertujuan untuk membuat model komunikasi yang efisien antara manusia dan mesin, sehingga mesin mampu menerima informasi melalui ucapan, beraksi dengan cepat dan tepat sesuai dengan informasi yang diberikan. Sistem pengenalan ucapan dibentuk melalui dua proses utama yaitu pelatihan (training) dan pengenalan (recognition). Pada penelitian ini, pelatihan dan pengujian menggunakan metoda Hidden Markov Model (HMM) dan ekstraksi ciri mengggunakan Mel-Frequency Cepstral Coeficient (MFCC). Ekstraksi ciri dilakukan untuk mendapatkan vektor ciri yang dapat merepresentasikan suatu ucapan. Pada tahap pelatihan, vektor ciri digunakan untuk membentuk model kata. Pada tahap pengenalan, vektor ciri akan dicocokan terhadap setiap model kata. Pada penelitian ini, sistem pengenalan ucapan dibangun dengan menggunakan HMM ToolKit (HTK) yang prosesnya ditunjukkan gambar 1 .

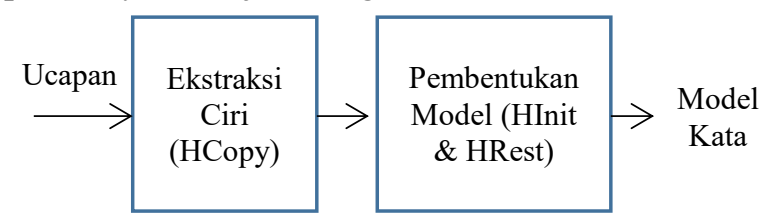

a). Tahapan Pelatihan

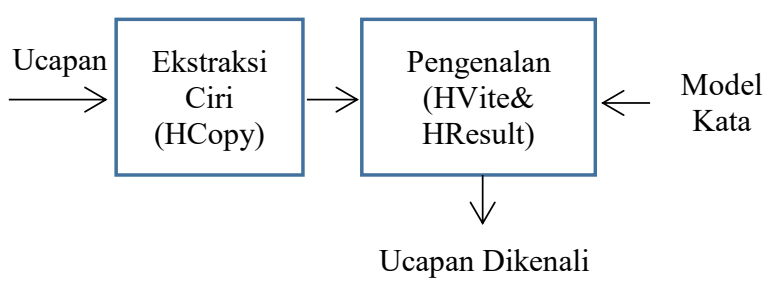

b). Tahapan Pengenalan

Gambar 1. Sistem Pengenalan Ucapan Menggunakan HTK

\subsection{Spectral Subtraction}

Spectral subtraction melakukan reduksi derau untuk memperbaiki dan meningkatkan SNR sinyal berderau seperti pada gambar 2 .

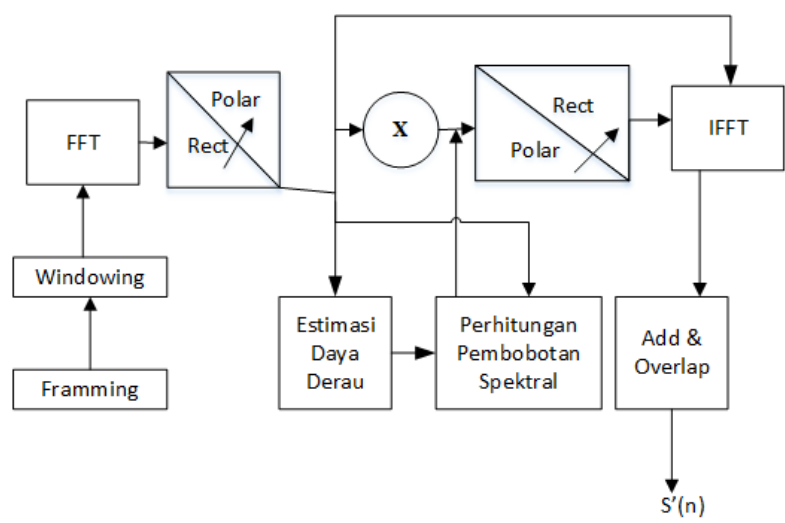

Gambar 2: Blok diagram spectral subtraction $y(n)=s(n)+d(n) \quad[13,14]$

Pada pre-processing dilakukan framing, windowing dan Fast Fourier Transform (FFT). Framing membagi sinyal menjadi frame-frame 
dengan durasi tertentu agar sinyal dapat dianggap stasioner. Windowing berfungsi meminimalkan efek ketidakkontinuan akibat framing. FFT untuk mengubah sinyal domain waktu ke domain frekuensi.

\subsubsection{Gaussian Window}

Idealnya, spektrum window memiliki mainlobe yang sempit dan side-lobe yang kecil[8]. Gaussian window mempunyai dua parameter yaitu panjang window (sama dengan panjang frame) dan redaman side-lobe $\left(\alpha_{g w}\right)$, sedangkan hamming window hanya memiliki satu paremeter yaitu panjang window. Gaussian window memiliki bentuk seperti persamaan (1) dan Hamming window seperti persamaan (2).

$$
\begin{aligned}
& w_{\text {gausian }}(n)=e^{-\frac{1}{2}\left(\alpha_{g w} \cdot \frac{n}{(N / 2}\right)^{2}}, 0 \leq|n| \leq \frac{N}{2} \\
& w(n)=0.54-0.46 \cos \left(\frac{2 \pi n}{N-1}\right) \\
& 0 \leq \mathrm{n} \leq \mathrm{N}-1
\end{aligned}
$$

\section{Dimana :}

$\mathrm{N}=$ panjang frame (jumlah cuplikan dalam satu frame)

$\alpha_{g w}=$ Redaman side lobe

\subsubsection{Estimasi derau Minimum statistik}

Pada metoda spectral subtraction, estimasi derau yang tepat sangat mempengaruhi kualitas sinyal hasil perbaikan. Jika estimasi derau terlalu rendah, maka akan terdengar sisa derau yang tidak natural, sedangkan jika terlalu tinggi maka bunyi ucapan akan teredam dan kejelasan akan berkurang.

Metoda minimum statistik berdasarkan pada asumsi bahwa selama jeda ucapan atau dalam perioda singkat antar kata dan silabel, energi ucapan mendekati atau sama dengan nol[10][13]. Sehingga dengan menelusuri daya minimum dalam suatu window maka noise floor dapat diestimasi. Pertama dihitung daya sinyal subband $\mathrm{P}(\mathrm{t}, \mathrm{k})$ dengan menggunakan smoothed periodogram seperti persamaan (3) [10][15] :

$$
P(t, k)=\alpha_{S} P(t-1, k)+\left(1-\alpha_{S}\right)|Y(t, k)|^{2}
$$

\section{(3)}

$\mathrm{P}(\mathrm{t}, \mathrm{k})$ adalah estimasi rapat spektral daya sinyal berderau dan $\alpha_{\text {s }}$ adalah parameter smoothing. Untuk derau yang tidak stasioner, dibutuhkan paramater smoothing yang berubah terhadap waktu dan frekuensi seperti persamaan (4) sampai persamaan (8) [10].

$$
\begin{aligned}
& P(t, k)=\alpha_{S}(t, k) P(t-1, k)+\left(1-\alpha_{S}(t, k)\right) \mid Y(t, k)^{2} \\
& \tilde{\alpha}_{S-C}(t)=\frac{1}{1+\left(\sum_{K=0}^{l-1} P(t-1, k) / \sum_{K=0}^{l-1}|Y(t, k)|^{2}-1\right)^{2}} \\
& \alpha_{S-C}(t)=0.7 \alpha_{S-C}(t-1)+0.3 \max \left(\widetilde{\alpha}_{S-C}(t), 0.7\right) \\
& \hat{\alpha}_{S}(t, k)=\frac{\alpha_{S} \max \alpha_{S-c}(t)}{1+\left(P(t-1, k) / \sigma_{N}^{2}(t-1, k)-1\right)^{2}} \\
& \alpha_{S-\min }=\min \left(0.3, S N R^{-\frac{R}{0.064 s f_{s}}}\right)
\end{aligned}
$$

nilai parameter smoothing yang selanjutnya digunakan adalah parameter pada persamaan (9) [10]

$$
\hat{\alpha}_{S_{-} a k h i r}(t, k)=\max \left(\hat{\alpha}_{S}(t, k), \alpha_{S-\min }\right)
$$

Pada proses pencarian minimum, window dengan panjang D diuraikan menjadi sejumlah $\mathrm{U}$ subwindow dengan panjang $\mathrm{V}$ sampel frame. Nilai minimum pada setiap subwindow $\left\{\mathrm{P}_{\text {actmin }}(\mathrm{t}, \mathrm{k})\right\}$ dan nilai minimum pada setiap sample $\left\{\mathrm{P}_{\text {actmin_sub }}(\mathrm{t}, \mathrm{k})\right\}$, diinisialisasi dengan nilai maksimum. Jika daya $\mathrm{P}_{\mathrm{y}}(\mathrm{t}, \mathrm{k})$ yang mendapatkan koreksi lebih kecil dari $\mathrm{P}_{\text {actmin }}(\mathrm{t}, \mathrm{k})$ maka didapatkan nilai $\mathrm{P}_{\text {actmin }}(\mathrm{t}, \mathrm{k})$ dan $\mathrm{P}_{\text {actmin_sub }}(\mathrm{t}, \mathrm{k})$ yang baru. Jika daya $\mathrm{P}_{\mathrm{y}}(\mathrm{t}, \mathrm{k})$ yang mendapatkan koreksi lebih besar dari $\mathrm{P}_{\mathrm{actmin}}(\mathrm{t}, \mathrm{k})$ maka digunakan nilai $\mathrm{P}_{\text {actmin }}(\mathrm{t}, \mathrm{k})$ dan nilai $P_{\text {actmin_sub }}(t, k)$ yang sebelumnya. Jika nilai $\mathrm{P}_{\text {actmin_sub }}(\mathrm{t}, \mathrm{k})$ lebih kecil dari nilai minimum sebelumnya $\left\{\mathrm{P}_{\min }(\mathrm{t}, \mathrm{k})\right\}$, maka nilai minimum yang baru adalah nilai $\mathrm{P}_{\text {actmin_sub }}(\mathrm{t}, \mathrm{k})$. Sedangkan, jika $P_{\text {actmin_sub }}(t, k)$ lebih besar dari nilai minimum sebelumnya, maka nilai minimum sekarang sama dengan minimum sebelumnya. Daya minimum yang diperoleh merupakan estimasi daya derau. $[10,13]$

\subsubsection{Berauti Spectral Subtraction}

Pada spectral subtraction domain daya, rentang nilai oversubtraction yang optimal adalah antara 3 dan 6 [16]. Rentang spectral floor berada pada 0.005 sampai 0.1 [6]. Belum ada metode optimasi untuk menetukan nilai faktor oversubtraction sehingga lebih merupakan pendekatan heuristik dan pada umumnya 
dilakukan secara empiris [17]. Pembobotan (gain) dapat dihitung dengan menggunakan persamaan (10a) dan (10b) [15]

$\operatorname{Jika}\left[\frac{|\widehat{D}(t, k)|^{2}}{|Y(t, k)|^{2}}\right]<\frac{1}{\alpha_{o S}+\beta_{S F}}$ maka:

$G(t, k)=\left(1-\alpha_{o s}\left[\frac{|\widehat{D}(t, k)|^{2}}{|Y(t, k)|^{2}}\right]\right)^{1 / 2}$

jika tidak:

$G(t, k)=\left(\beta_{S F}\left[\frac{|\widehat{D}(t, k)|^{2}}{|Y(t, k)|^{2}}\right]\right)^{1 / 2}$

Spektral daya sinyal ucapan bersih (tanpa derau) diestimasi dengan menggunakan persamaan (11).

$|\hat{S}(t, k)|^{2}=G(t, k) \cdot|Y(t, k)|^{2}$

Untuk mengembalikan ke domain waktu digunakan Inverse Transformasi Fourier dan phasa sinyal berderau.

\section{Metoda Penelitian}

Tahapan penelitian yang telah dilakukan dijelaskan dalam tahapan sebagai berikut.

Pengumpulan data penelitian dimana data ucapan direkam dalam lingkungan tenang dengan spesifikasi perekaman frekuensi sampling $8 \mathrm{Khz}$, durasi sampel kata 1 detik, jumlah sumber suara 15 orang, 10 ucapan untuk setiap angka dari setiap sumber, sehingga total data ucapan 1500 ucapan. Kosakata adalah angka bahasa Indonesia nol, satu, dua, tiga, empat, lima, enam, tujuh, delapan, sembilan. Jenis derau yang digunakan AWGN, derau Suara Mobil dan derau suara pengering rambut. Level SNR yang diuji adalah $0 \mathrm{~dB}, 5 \mathrm{~dB}, 10 \mathrm{~dB}$, $15 \mathrm{~dB}$ dan $20 \mathrm{~dB}$

Selanjutnya dibentuk sistem pengenalan ucapan pada lingkungan tenang. Sistem dibentuk dengan topologi Bakis Model, ekstraksi ciri metoda MFCC 26 koefisien, dilakukan variasi ukuran model (jumlah state dan jumlah mixture). Pemodelan dilakukan menggunakan 560 ucapan yang berasal dari 8 orang

Kemudian dilakukan pengujian/pengenalan terhadap sinyal ucapan tanpa derau sebanyak 1500 ucapan, untuk mengetahui akurasi pengenalan ucapan pada lingkungan tenang.

Pengenalan terhadap sinyal ucapan berderau untuk mengetahui pengaruh derau terhadap akurasi sistem. Pengujian ini menggunakan data pengujian $=1500$ ucapan $\times 3$ jenis derau $\times 5$ level SNR $=22500$ sinyal ucapan berderau

Untuk perancangan Spectral subtraction digunakan : ukuran frame $32 \mathrm{~ms}$ dan overlap 50 $\%$. Pada proses windowing menggunakan Gaussian window dengan memvariasi parameter nilai redaman sidelobe. Estimasi Derau dilakukan dengan menggunakan metoda minimum statistik. Pada Berauti Spectral Subtraction dengan variasi nilai oversubtraction dan spectral floor 0.01 .

Memperbaiki 22500 sinyal ucapan berderau. Pengenalan terhadap 22500 sinyal ucapan berderau yang telah diperbaiki. Hal ini untuk mengetahui kinerja Spectral subtraction yang diusulkan dalam mengatasi derau. Persen akurasi pengenalan dapat dihitung dengan persamaan (12)

$\%$ akurasi $=\frac{A}{B} \times 100 \%$

Dimana :

A = Jumah ucapan dikenali dengan Benar $\mathrm{B}=$ Jumlah ucapan yang diujikan

\section{Hasil dan Pembahasan}

Persentase peningkatan akurasi merupakan selisih antara persentase akurasi pengenalan terhadap sinyal ucapan berderau sebelum diperbaiki dengan persentase akurasi pengenalan terhadap sinyal ucapan berderau yang telah diperbaki dengan menggunakan metoda spectral subtraction yang diusulkan. Peningkatan akurasi sinya hasil perbaikan dengan spectral subtraction menggunakan Hamming window dibandingkan terhadap Gaussian Window dengan beberapa variasi nilai redaman sidelobe. Hasil pengujian ditunjukkan oleh gambar 4 sampai 6 dan untuk setiap gambar legend grafik yang digunakan ditunjukkan oleh gambar 3.

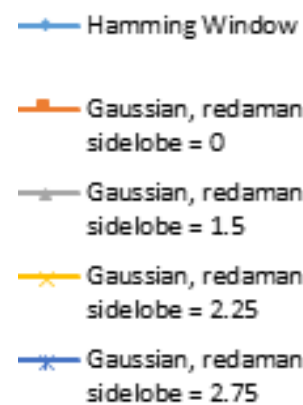

Gambar 3. Legend untuk grafik pada gambar 4-6. 
Hasil pengujian yang dilakukan terhadap sinyal ucapan berderau AWGN ditunjukan pada gambar 4, terhadap sinyal ucapan berderau suara mobil ditunjukan pada gambar 5 dan sinyal berderau suara pengering rambut ditunjukan pada gambar 6 .

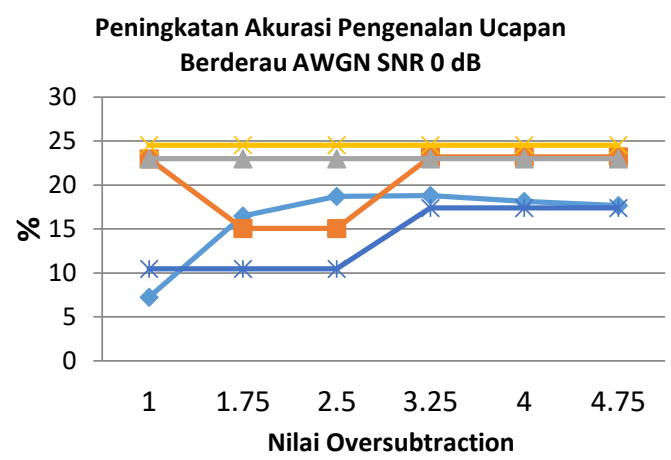

(a)

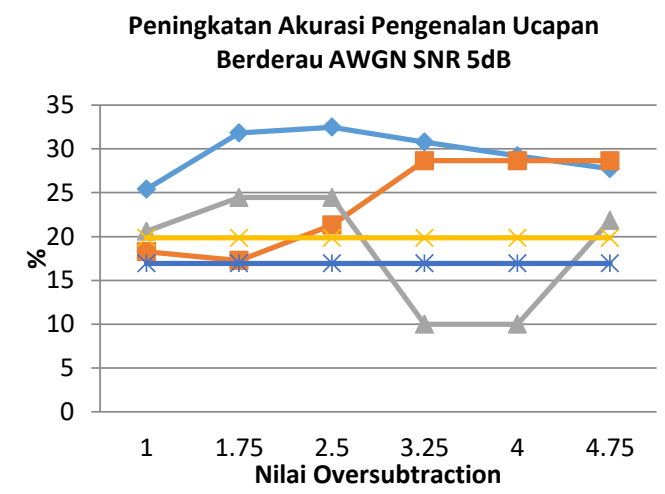

(b)

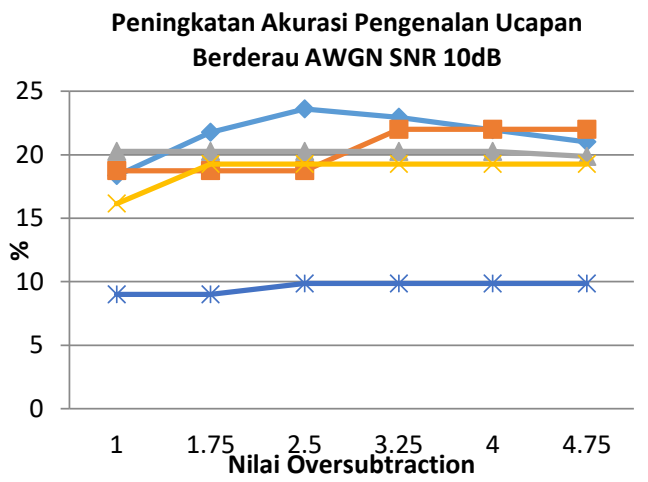

(c)

Gambar 4. Peningkatan akurasi pengenalan ucapan berderau AWGN yang diperbaiki menggunakan Spectral subtraction pada SNR 0, 5, $10 \mathrm{~dB}$

Gambar 5 dapat menunjukan peningkatan akurasi pengenalan ucapan berderau suara mobil yang telah diperbaiki oleh metoda spectral subtraction menggunakan gaussian window, memberikan hasil persentase yang lebih tinggi dibandingkan hamming window. Hal ini juga terjadi pada sinyal berderau dengan level SNR $15 \mathrm{~dB}$ dan $20 \mathrm{~dB}$. Penggunaan hamming window memberikan peningkatan akurasi maksimum pada nilai oversubtraction 2.5 dan menurun untuk nilai oversubtraction yang lebih besar. Hal ini terjadi pada semua level SNR. Rata-rata peningkatan akurasi pengenalan sinyal berderau suara mobil dengan menggunakan hamming window sebesar $20,71 \%$ pada nilai oversubtraction 2.5.

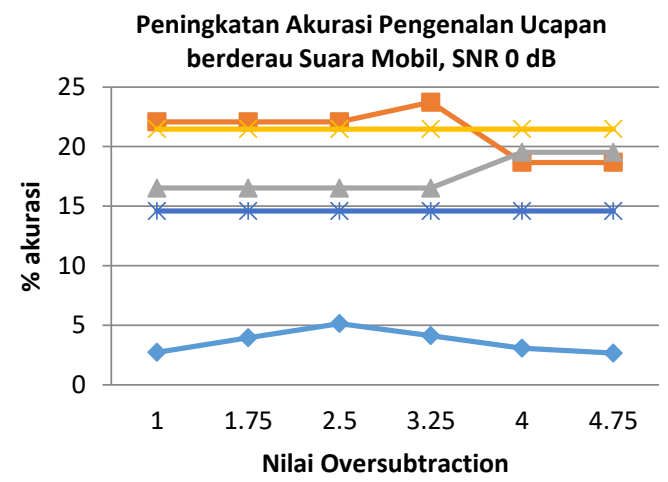

(a)

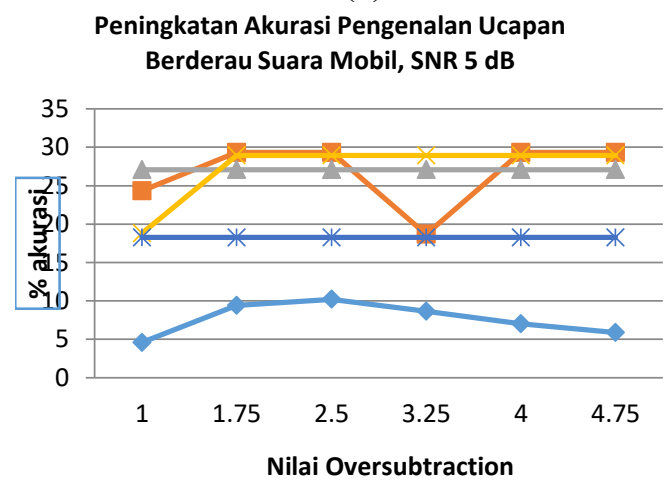

(b)

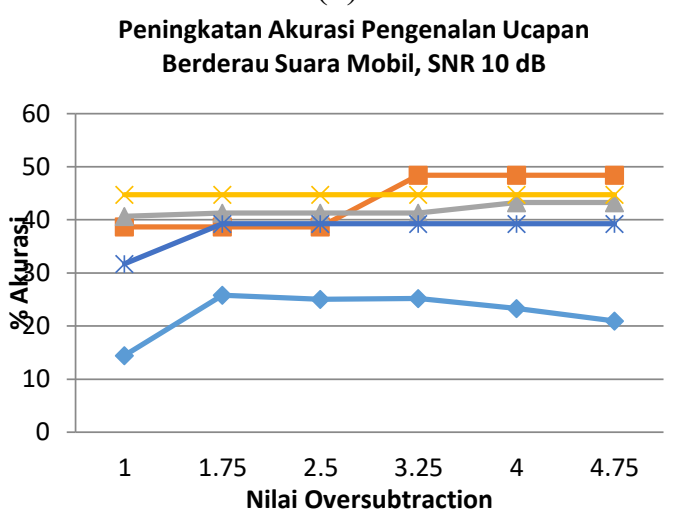

(c)

Gambar 5. Peningkatan akurasi pengenalan ucapan berderau suara mobil yang 
diperbaiki menggunakan Spectral pada SNR 0, 5, $10 \mathrm{~dB}$

Penggunaaan gaussian window memberikan peningkatan akurasi pengenalan sebesar $46,94 \%$ pada nilai oversubtraction 4,75 dan redaman sidelobe 1.5. Karena itu, penggunakan gaussian window pada metoda spectral subtration untuk memperbaiki kualitas sinyal berderau suara mobil, memberikan peningkatan akurasi yang lebih baik dibandingkan hamming window.

Gambar 6 menunjukan bahwa peningkatan akurasi pengenala ucapan berderau suara pengering rambut (Hair Dryer) yang telah diperbaiki oleh metoda spectral subtraction menggunakan gaussian window, memberikan persentase peningkatan pengenalan ucapan yang lebih tinggi dibandingkan hamming window. Hal ini juga terjadi pada sinyal berderau dengan level SNR $15 \mathrm{~dB}$ dan $20 \mathrm{~dB}$. Pada setiap level SNR, peningkatan akurasi maksimum pada hamming window berada pada nilai oversubtraction 2.5 dan menurun untuk nilai oversubtraction yang lebih besar. Rata-rata peningkatan akurasi pengenalan sinyal berderau suara penegring rambut dengan menggunakan hamming window sebesar $14.45 \%$ pada nilai oversubtraction 2.5. Gaussian window memberikan rata-rata peningkatan akurasi pengenalan sebesar 45,32 \% pada oversubtraction 4 dan redaman sidelobe 1.5.

Secara keseluruhan, gaussian window memiliki rata-rata peningkatan akurasi pengenalan ucapan sebesar $36,4 \%$ diperoleh pada nilai oversubtraction 4.75 dan redaman sidelobe 1.5. Hamming window memiliki ratarata peningkatan akurasi pengenalan sebesar $18,7 \%$ pada nilai oversubtraction 2.5. Oleh karena itu, penggunaan gaussian window memberikan peningkatan akurasi yang lebih baik dibandingkan hamming window. Pada gaussian window, terlihat bahwa semakin besar atau kecil nilai redaman sidelobe tidak menjamin peningkatan akurasi pengenalan, seperti halnya pada nilai oversubtraction. Oleh karena itu pemilihan nilai oversubtraction dan redaman sidelobe mempengaruhi akurasi pengenalan ucapan.

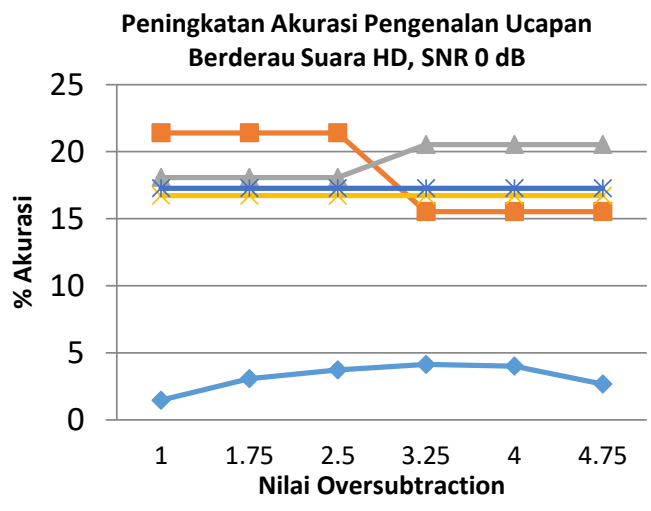

(a)

Peningkatan Akurasi Pengenalan Ucapan Berderau HD, SNR 5 dB

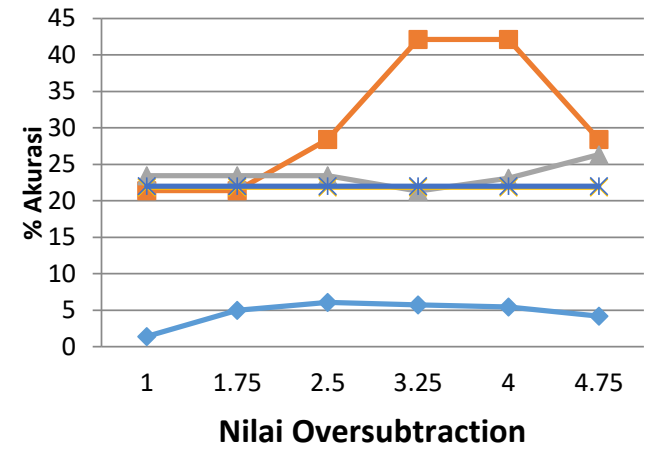

(b)

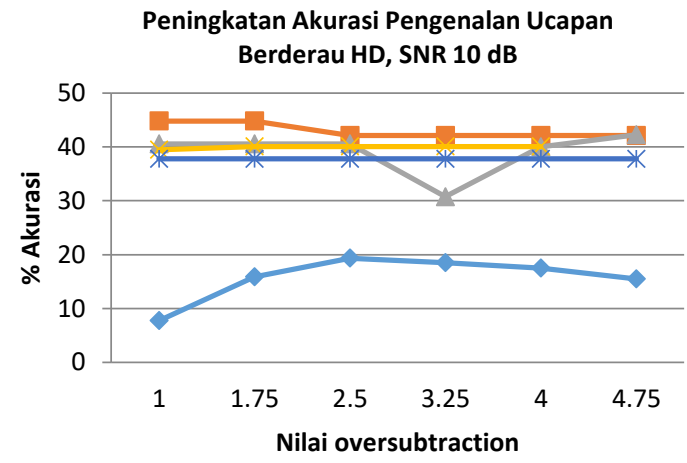

(c)

Gambar 6. Peningkatan akurasi pengenalan ucapan berderau suara hair dryer yang diperbaiki pada SNR 0, 5, 10 $\mathrm{dB}$

\section{Kesimpulan}

Berdasarakan penelitian yang telah dilakukan, dapat disimpulkan bahwa metoda Berauti spectral subtraction yang menerapkan gaussian window dengan estimasi derau minimum statistik mampu memperbaiki kualitas sinyal berderau sehingga dapat meningkatkan akurasi 
pengenalan ucapan berderau. Penggunaan gaussian window pada metoda spectral subtraction mampu memberikan peningkatan akurasi yang lebih baik dibandingkan hamming window. Pemilihan nilai oversubtraction dan redaman sidelobe menentukan besarnya peningkatan akurasi pegenalan ucapan.

\section{Ucapan Terima Kasih}

Terima kasih disampaikan kepada Jurusan Teknik Elektro Fakultas Teknik Universitas Andalas yang telah memberikan dana penelitian DIPA Fakultas Teknik dengan nomor kontrak : 095/UN.16.09.D/PL/2017

\section{Daftar Pustaka}

[1] Li, J., Deng, L., Yu, D., Gong, Y., \& Acero, A., "High-performance HMM adaptation with joint compensation of additive and convolutive distortions via vector Taylor series." In Automatic Speech Recognition \& Understanding, ASRU. IEEE Workshop on pp. 65-70. 2007.

[2] Xiao Xiong. Speech Enhancement with Applications in Speech Recognition. Nanyang Technological University, 2006

[3] Gales, Mark John Francis. "Model-based techniques for noise robust speech recognition." $\mathrm{PhD}$ diss., University of Cambridge, 1995.

[4] Arun Narayanan, Xiaojia Zhao., DeLiang Wang, Eric Fosler-Lussier. "Robust Speech Recognitiion Using Multiple Prior Models For Reconstructon". ICASSP - IEEE. 2011;4800-48003

[5] Boll: "Suppression of acoustic noise in speech using spectral subtraction", IEEE Trans. Acoust. Speech and Sig. Proc., 27:113-120, 1979.

[6] M. Berouti, R. Schwartz, J. Makhoul, "Enhancement of speech corrupted by acoustic noise", Proc. IEEE ICASSP, 208$211,1979$.

[7] Harald Gustafsson, Sven Nordholm and Ingvar Claesson, "Spectral Subtraction With Adaptive Averaging Of The Gain Function", 6th European Conference on Speech Communication and Technology (EUROSPEECH'99) Budapest, Hungary, September 5-9, 1999
[8] S. China Venkateswarlu, A. Subba Rami Reddy \& K. Satya Prasad, "Speech Enhancement using Boll's Spectral Subtraction Method based on Gaussian Window", Global Journal of Researches in Engineering: Electrical and Electronics Engineering Vol. 14 Issue 6 Version 1.02014

[9] A. M. Kandoz, Digital speech, 2nd edition, Willey, 2002.

[10] Martin, Rainer. "Noise power spectral density estimation based on optimal smoothing and minimum statistics." IEEE Transactions on speech and audio processing Vol.9 No.5 pp.504-512, 2001.

[11] Urmila Shrawankar, Vilas Thakare. An "Adaptive Methodology for Ubiquitous ASR System", Computer and Information Science, vol 6 no.1, pp 58-69, 2013

[12] Fitrilina ., Rahmadi Kurnia, Siska Aulia, "Pengenalan Ucapan Metoda MFCCHMM Untuk Perintah Gerak Robot Mobil Penjejak Identifikasi Warna", Jurnal Nasional Teknik Elektro (JNTE) Vol 2,No 1: Maret 2013

[13] Fitrilina, "Sistem Pengenalan Isolated Digit yang Robust Dengan Menggunakan Spectral Subtraction Berdasarkan Minimum Statistics", Jurnal Teknika No 35 Vol 1. 2011,

[14] Venkata Rami Reddy Datla, "Implementation and evaluation of spectral subtraction (SS) with minimum statistics and wiener beamformer combination". Master Thesis of Electrical Engineering, school of Engineeringctrical Engineering ,Blekinge Institute of Technology (BTH), Sweden. 2013

[15] Martin, Rainer. "Spectral subtraction based on minimum statistics." Power V6 n.8, 1994

[16] Bhatnagar, Mukul, "Modified Spectral Subtraction Method Combine With Percetual Weighting for Speech Enhancement", Thesis, The University of Texas, Dallas, 2002

[17] Hilman F. Pardede, "Nonlinear Spectral Subtraction Berbasis Tsallis Statistics untuk Peningkatan Kualitas Sinyal Ucapan", INKOM, Vol. 7, No. 1, 2013.

\section{Biodata Penulis}

https://doi.org/10.25077/ jnte.v7n3.497.2018 jnte.ft.unand.ac.id 
Fitrilina, Menamatkan S1 di Teknik Elektro Fakultas Teknik Universitas Andalas tahun 2005. Menamatkan S2di Teknik Elektro STEI-ITB tahun 2010. Saat ini terdaftar sebagai staf pengajar di Jurusan Teknik Elektro FT UNAND
Winda Alfin, Menamatkan S1 di Teknik Elektro Fakultas Teknik Universitas Andalas tahun 2017

Fajar Afriyansah, Menamatkan S1 di Teknik Elektro Fakultas Teknik Universitas Andalas tahun 2016. 